\title{
Indices of Free Testosterone And Hyperandrogenemia in Relation To Hirsutism in Middle Aged Egyptian females
}

\author{
*Kandil H.T., * Hassan Z.A., * Abaza D.M. ** Abd. El Fattah . A.M. \\ * Endocrinology and ** clinical pathology \\ Departments- Al- Azhar university (Girls)
}

\begin{abstract}
Hirsutism is an androgen excess related disorder that commonly affects women causing a variety of negative metabolic disturbances. Early and accurate diagnoses of androgen overproduction or hypersensitivity to normal circulating androgen have an important implication for treatment and follow up of patients.

The aim of this work is to study the validity of hyperandrogonemic index (HAI) and index of free testosterone (IFT) in, diagnosis of hirsute Egyptian women, and its correlation to hair score as a clinical marker for hirsutism.

Twenty-four hirsute women aged 19-32 y's, median (24.25 \pm 4.3$)$ were studied. Ten age matched nonhirsute females, were studied as controls. Patients and control were subjected to the following, full history and clinical examination. Biochemical and hormonal parameters were measured, fasting blood sugar (FBLS), 2 hours post prandial blood sugar ( $2 \mathrm{~h}$ pp BL. S), serum total testosterone (TT), free testosterone (FT), dihydroepiandrosterone (DHEA), Dihydroepiandrosterone sulphate (DHEAS) androstenedion (ADION), prolactin (PL) and sex hormone binding globulin (SHBG). Index of free testosterone (IFT) and index of hyperandrogenemia (IHA) were calculated. Results showed significant higher $\mathrm{BMI}(\mathrm{P}<0.009)$, 2 hrs PPBLS. $(\mathrm{P}<0.001)$, TT $(\mathrm{P}<0.005)$, FT $(\mathrm{P}<0.000)$, SHBG $(\mathrm{P}<0.02)$ and $(\mathrm{ADION})(\mathrm{P}<$ 0.000 ) in hirsute females compared to controls. Hair score was positively correlated with IFT only while it was not correlated with all of the measured hormones.

FT was positively correlated with BMI $(\mathrm{P}<0.004)$, FBLS $(\mathrm{P}<0.001)$ and $2 \mathrm{hrs} \mathrm{PPBL} . \mathrm{S}(\mathrm{P}<$ $0.000)$. While TT was positively correlated with BMI $(\mathrm{P}<0.001)$. Androstenedion was positively correlated with systolic BL.P $(\mathrm{P}<0.000)$, diastolic BL.P $(\mathrm{P}<0.02)$, FBL.S $(\mathrm{P}<0.001)$ and 2 hrs PPBL.S $(\mathrm{P}<0.000)$. IFT was positively correlated with hair score $(\mathrm{P}<0.05)$, BMI $(\mathrm{P}<$ 0.01), systolic BL.P $(\mathrm{P}<0.004)$, FBL.S $(\mathrm{P}<0.001)$ and $2 \mathrm{hrs} \mathrm{PPBL} . \mathrm{S}(\mathrm{P}<0.01)$.

SHBG was negatively correlated with systolic BL.P $(\mathrm{P}<0.04)$, FBL.S $(\mathrm{P}<0.05)$ and $2 \mathrm{hrs}$ PPBL.S $(\mathrm{P}<0.03)$.
\end{abstract}

\section{Conclusion}

Hirsutism is a clinical symptom associated with hyperandrogenism. It must be diagnosed accurately, and as early as possible. The most accurate diagnostic measurement is IFT rather than IHA or other hormones individually.

Hirsutism must be studied in depth not as a simple complaint, as it may be the entrance to the more complex metabolic syndrome.

IFT is beneficial in diagnosis of borderline hirsute women.

\section{Introduction}

Hirsutism is one of the most common endocrine disorders in women of fertile age. In these women, the hairiness implies the presence of abnormal androgen level / or action, which may represent a serious or, more likely, a nonserious medical problem; (George et al 2003).

Increased androgen production causes welldocumented negative metabolic changes, (Conway et al 1992). Those women are at 


\section{Kandil H.T et al}

substantially higher risk of hypertension, coronary artery disease and non-insulin dependent diabetes mellitus, (Dahlgren et al 1992 and cibula et al 2000).

Proper diagnosis of hirsutism and / or hyperandrogenism is very important from the clinical point of view and has implications for future treatment and follow up of patients. Abdominal and pelvic examination is important in patients with hirsutism because more than half of them are due to ovarian or adrenal cause, while idiopathic hirsutism is common also, it is diagnosed by exclusion of other causes (Gold Zieher + Young., 1992).

Examination of the skin for acanthosis nigricans and body mass index are of importance, as a manifestation of insulin resistance which may be associated with increasing risks of hypertension and coronary heart disease (Wild, 1995).

The spectrum of clinical presentations of hirsute women ranges from normal menses and mild hirsutism to amenorrhea and signs of virilization. Testosterone ranges from normal to frank elevation (Smith et al 1979). In idiopathic hirsutism the most often reported parameter is the level of testosterone or index of free testosterone (IFT), but increased levels of androstenedione (representing the 5 $\alpha$-reductase enzyme activity) and/or other androgen precursors is the only finding in many patients. More over the androgen levels may be found close to the upper or lower reference value and may be not accurate in diagnosis of hirsute case (Hatch et al 1981).

\section{Aim of the work}

To study the validity of Index of hyperandrogenemia (IHA) and Index of free Testosterone (IFT) in diagnosis of hirsute Egyptian women, and its correlation to hair score as a clinical marker for hirsutism.

\section{Subjects and methods}

The present study included 24 hirsute young women aged (19-32 years), median $(24.25 \pm 4.3)$. They were selected from the outpatient clinic of Endocrinology
Department Al-Zahraa university hospital from 2001 through 2002 year. Exclusion criteria included history of medication that may affect hair growth, ovarian dysfunction that may cause hormonal disturbances in the preceding three months. Endocrinal disorders including thyroid dysfunction Cushing's syndrome and diabetes mellitus. Other cardiac, chest or abdominal illnesses were also excluded. Ten age matched non hirsute women without clinical or hormonal evidence of endocrine disease served as controls. All women participating in the study gave their informed consent.

\section{Methods}

All women included in the study were subjected to the following : full history taking included onset of hirsutism, menstrual history and family history of similar condition. Clinical examination included, pulse, arterial blood pressure measurements. Anthropometric measurements, included body height and weight. Body mass index (BMI) was calculated as weight in kilogram divided by the square of height in meter (flier and faster 1997).

Acne, acanthosis nigricance were also examined.

Increased body hair was graded using Ferriman and Galway methods (F-G score). Hirsutism was defined as (F-G score) greater than 6 (Ferriman and Gallaway 1961, Knochemhaver et al 1998). Fasting and $2 \mathrm{hrs}$ postprandial blood sugar were measured.

Hormonal assays: blood samples were collected from all women in the early follicular phase "between day 3 and 6 of the menstrual cycle" then allowed to clot at room temperature, and centrifuged. Separated serum was collected and frozen at- $20 \mathrm{c}^{\mathrm{o}}$ until estimation. The following parameters were evaluated; total, free testosterone and androstenedione were assessed by radioimmunoassay method (Judd and Yen., 1973). DHEA, DHEA-S and SHBG were measured by using radioimmunoassay method (ImmunotechIOT, Marseille, France). Kit from Gamatrade company (Abraham 1979). 
The index of free testosterone (IFT) was calculated based on the levels of total testosterone and SHBG according to the formula:

\section{IFT=100XT (nm/L1/SHBG nmol/L)}

The index of hyperandrogenemia (IHA) was calculated according to the following formula

$\mathrm{IHA}=5 \sqrt{\text { IFT X ADTON X DHEA X DHEAS }}$
The fifth root in the formula was chosen for the best approximation to gaussion data distribution enabling the utilization of simple statistical methods (Cibula et al., 2000).

The reference values for normal hormonal levels were as follow: T.T (0.5$2.63 \mathrm{mg} / \mathrm{l})$, FT $(0.8-1.9 \mathrm{mg} / \mathrm{l})$, androstonedione (1.57-5.4 nmol) DHEA (0.8-10.5 mg/l), DHEA-S (2.4-14.5 M $\mathrm{mol} / \mathrm{l})$ and SHBG (43.2-96.0 nmol/L).

Table (1): Mean \pm SD of Demographic, Clinical Parameters, in Hirsute and Control Groups:

\begin{tabular}{|c|c|c|c|c|}
\hline Parameters & Hirsute & Control & T & P \\
\hline Age in years & $24.25 \pm 4.33$ & $25.1 \pm 5.13$ & -0.495 & $>0.05$ \\
BMI Kg/m2 & $30.37 \pm 3.21$ & $27.0 \pm 3.23$ & 0.278 & $0.009^{*}$ \\
Age of menarche & $12.83 \pm 0.82$ & $12.9 \pm 1.1$ & -0.196 & $>0.05$ \\
Systolic B1/P & $121.25 \pm 12.87$ & $118.5 \pm 12.48$ & 0.572 & $>0.05$ \\
Diast B1/.P & $79.38 \pm 8.08$ & $77.0 \pm 7.89$ & 0.75 & $>0.05$ \\
\hline
\end{tabular}

*Significant higher BMI in hirsute compared to control group

Table (2): Mean \pm SD of Biochemical and Hormonal Parameters in Both Hirsute and Control Groups.

\begin{tabular}{|l|c|c|c|c|}
\hline & Hirsute & Control & $\mathrm{T}$ & $\mathrm{P}$ \\
\hline FBL.S mg/dl & $92.04 \pm 13.2$ & $82.8 \pm 9.64$ & 1.86 & $>0.05$ \\
\hline 2hrs PPBL.S mg/dl & $110.58 \pm 12.42$ & $94.2 \pm 9.5$ & 3.73 & $<0.001^{*}$ \\
\hline TT & $1.06 \pm 0.43$ & $0.63 \pm 0.2$ & 3.01 & $0.005^{*}$ \\
\hline FT & $2.16 \pm 0.8$ & $0.88 \pm 0.4$ & 4.75 & $<0.000^{*}$ \\
\hline DHEA & $9.32 \pm 7.95$ & $5.1 \pm 2.05$ & 1.64 & $>0.05$ \\
\hline DHEAS & $6.56 \pm 4.54$ & $3.71 \pm 1.59$ & 1.92 & $>0.05$ \\
\hline Prolactin & $12.22 \pm 3.25$ & $9.13 \pm 4.1$ & 2.1 & $0.044^{*}$ \\
\hline SHBG & $67.5 \pm 22.59$ & $88.0 \pm 14.07$ & -2.39 & $0.02^{*}$ \\
\hline ADION & $15.87 \pm 5.98$ & $7.67 \pm 1.9$ & 4.27 & $0.000^{*}$ \\
\hline
\end{tabular}

*Significant difference in 2h.P.P.Bl.s, TT, FT, prolactin, SHBG and ADION in hirsute compared to control group. 
Table (3) Correlation Between Hair Score, Clinical Data and Blood Sugar with Different Hormonal Values in Hirsute Group

\begin{tabular}{|c|c|c|c|c|c|c|}
\hline \multirow{2}{*}{ Parameters } & \multirow{2}{*}{ Hair score } & \multirow{2}{*}{ BMI kg/m2 } & \multicolumn{2}{|c|}{ Blood pressure $\mathrm{mm} / \mathrm{hg}$} & \multicolumn{2}{|c|}{ B1. Sugar mg/dl } \\
\hline & & & Systolic & Diastolic & Fasting & PP Bl.s \\
\hline TT & Ns & $\begin{array}{l}\text { ro.677 } \\
\mathrm{P}<0.001 * *\end{array}$ & Ns & Ns & Ns & Ns \\
\hline FT & NS & $\begin{array}{l}\text { Ro. } 4 / 5 \\
\text { P }<0.04^{*}\end{array}$ & Ns & Ns & $\begin{array}{l}\text { ro. } 643 \\
\mathrm{P}<0.001 * *\end{array}$ & $\begin{array}{l}\mathrm{r} 0.654 \\
\mathrm{P}<0.001 * *\end{array}$ \\
\hline SHBG & NS & NS & $\begin{array}{l}\mathrm{r}-0.406 \\
\mathrm{P}<0.04 *\end{array}$ & Ns & $\begin{array}{l}\mathrm{r}-0.400 \\
\mathrm{P}<0.05^{*}\end{array}$ & $\begin{array}{l}\mathrm{r}-0.433 \\
\mathrm{P}<0.03^{*}\end{array}$ \\
\hline ADION & Ns & Ns & $\begin{array}{l}\mathrm{r}-0.669 \\
\mathrm{p}<0.000^{* *}\end{array}$ & $\begin{array}{l}\mathrm{r}-0.456 \\
\mathrm{p}<0.02^{*}\end{array}$ & $\begin{array}{l}\mathrm{r}-0.644 \\
\mathrm{p}<0.001 * *\end{array}$ & $\begin{array}{l}\mathrm{r}-0.710 \\
\mathrm{p}<0.000^{* *}\end{array}$ \\
\hline IFT & $\begin{array}{l}0.508 \\
\mathrm{P}<0.05 *\end{array}$ & $\begin{array}{l}\mathrm{r}-0.517 \\
\mathrm{p}<0.01 * *\end{array}$ & $\begin{array}{l}\mathrm{r}-0.569 \\
\mathrm{p}<0.004 * *\end{array}$ & NS & $\begin{array}{l}\mathrm{r}-0.642 \\
\mathrm{p}<0.001 * *\end{array}$ & $\begin{array}{l}\mathrm{r}-0.508 \\
\mathrm{p}<0.01 * *\end{array}$ \\
\hline IHA. & NS & NS & NS & NS & NS & NS \\
\hline
\end{tabular}

* Significant correlation at $\mathrm{p}$ value $<0.05$

** Significant correlation at $\mathrm{p}$ value $<0.01$

Table 3 showed

Positive correlation between hair score and IFT only

○ BMI positively correlated with TT, FT and IFT

- Systolic Bl. P positively correlated with ADION \& IFT

- Diastolic Bl p positively correlated with ADION

- Fasting \& 2hs PP Bl-s was positively correlated with FT, ADION \& IFT while negative correlation was found between SHBG and systolic Blood pressure fasting and $2 \mathrm{~h}$ PP Bl. sugar

\section{Discussion}

Hirsutism is one of the most common endocrinal disorders. About $8 \%$ of racially mixed, non hospital- based female population showed evidence of mild hirsutism (ferryman Gallwey scor> 6)

(Konchenhaver et al., 1998). Others rely on biochemical evaluation as opposed to clinical criteria to document hyperandrogenism. Most commonly, this is done with serum assay to document elevation in circulating androgen levels, (Ayala et al., 1999 and Penttila et al., 1999).

While 60 to $80 \%$ of women with hirsutism have increased levels of circulating androgens, degree of hirsutism correlates poorly with androgen levels, (Carmina and lobo 1991).

In the present study we compared the significance of clinical findings as well as the laboratory and hormonal levels in both hirsute and non-hirsute group. Also we correlated hair score (F-G score) with all studied hormones, IFT and IHA as a trial to 


\section{Indices of Free Testosterone And Hyperandrogenemia}

find the most accurate and reliable method for diagnosis of hyperandrogenemia.

As regard the clinical findings we found significant higher BMI in hirsute compared to control group. The same result was found by Nike et al., (2003) and Dunaif et al., (1989). They found that BMI was significantly higher in hirsute compared to controls.

In this study, correlating BMI with all studied hormones, revealed positive correlation with TT, FT and IFT. Insignificant correlation was found with the other studied androgenic hormones.

In the current study we found significant elevated $2 \mathrm{hs}$. Postprandial blood sugar in hirsute group compared to control and non significant difference between F.B1.s among both groups. These results are in agreement with Wild (1995) and Dunaif, (1995), who found strong relationship between hyperandrogenism and insulin resistance type 2 diabetes, hypertension and PCOS.

In the current study, we correlated fasting and $2 \mathrm{hs}$ post prandial blood sugar with different studied hormones. Significant positive correlation was found with free testosterone and androstenedione only. In agreement with our results (Conway et al., 1992), found that impaired glucose tolerance and type 2 diabetes were found in 40 to $45 \%$ of patients with PCOS and hyperandrogenism. Also Legro et al.,(1999) and Ehrmann et al (1999), reported the presence of hyperinsulinemia and insulin resistance with glucose intolerance in women with hyperandrogenemia associated with PCOS. Hyperglycemia found in our cases could be explained by hyperinsulinemia and insulin resistance, which may be induced by obesity or hyperandrogenemia. SHBG was negatively significant with both fasting and 2 hrs postprandial Blood sugar. This negative correlation may be due to associated low total testosterone with increased SHBG.

Ehrmann et al., (1995) reported that undiagnosed type 2 diabetes mellitus is very prevalent, and the rate of conversion to frank type 2 diabetes is at least five folds in obese hyperandrogenemic PCOS women compared to normal.
In the present study correlation of blood pressure changes with different hormonal levels revealed positive correlation between androstenedione with systolic and diastolic blood pressure. These results are mostly due to increased $5 \alpha$ reductase enzyme activity, which leads to increased response to the circulating androgen, which may leads to hirsutism, insulin resistance and PCOS which is strongly related to dyslipidemia and coronary heart disease. Negative correlation was found between SHBG and systolic blood pressure. This result may be due to decreased level of free testosterone associated with increased SHBG. Similar results were found by (Conway 1992 and Garg, 1998).

Kieren et al., (2000) and Conway et al (1992) reported that hyperandrogenemia associated with PCOS is usually accompanied by hyperinsulinemia, insulin resistance, hyperlipidemia, hypertension and associated risk of coronary heart disease.

In the present study we correlated hair score (FG- Score) with different hormonal parameters, IFT and IHA. Significant positive correlation was found with IFT and not with IHA or other hormones.

Haseltine et al., (1994) demonstrated a highly significant correlation between F$\mathrm{G}$ score and IFT as well as DHEA. Cibula et al (2000), studied the F-G score with all androgenic hormones as well as IFT and IHA and found that the strongest relationship was between F-G score and IHA, correlation was significant also with androstenedione and DHEA, while it was insignificant with IFT.

The difference between our results and the other may be due to small number of studied group, low mean value of FGscore of these patients $(9.3 \pm 2.1)$. The studied hormones were mildly elevated and most of them were closely near to high normal values.

Diagnosis of hirsutism is usually not dependent on single hormone measurement because free testosterone level may increase in case of decreased sex hormone binding globulin, also the other androgenic hormones may be mildly elevated, so accurate 
diagnosis of hyperandrogenemia is multi hormonal dependent formula which may diagnose the presence of hyperandrogenism but not diagnostic to the cause of hyperandrogenism, that needs another investigations.

\section{Conclusion}

Hirsutism is a clinical symptom associated with hyperandrogenism. It must be diagnosed accurately and as early as possible. The most accurate diagnostic measurement is IFT rather than IHA or other hormones individually.

Hirsutism must be studied in depth not as a simple complaint as it may be the entrance to the more complex metabolic syndrome.

IFT is beneficial in diagnosis of borderline hirsute women.

\section{Reference}

1. Abraham G (1977): Ovarian and adrenal contribution to peripheral Androgens During the Menstrual Cycle J. Clin. Endorin, metals 39; 340.

2. Ayala C, Steinberger E, Smith KD. (1999): serum testosterone levels and reference ranges in reproductive- age women. Endocr pract.; 5; 322- 329.

3. Carmina E, Lobo RA (1991): peripheral androgen blockade versus glandular androgen suppression in the treatment of hirsutism. Obst. Gynecol; 78 (PTN): 845849.

4. Cibula D, Cifkova R, Fanta $M$ et al.,(2000): Increased risk of non insulin dependent diabetes mellitus, arterial hypertension and coronary artery disease in perimenopausal women with a history of the polycystic ovary syndrome. Hum Repord; 15: 785- 789.

5. Cibula D, Hill M and Starka L (2000): The best correlation of the new index of hyperandrogenism with the grade of increased body hair. Europiun Journal of Endocrinology; 143: 405- 408.

6. Conway GS, Agrawal R, Betteridge DJ, Jacobs HS; (1992): Risk factors for coronary artery disease in lean and obese women with the poly cystic ovary syndrome. Clin. Endocrin. (OXF); 37: 199- 125.

7. Dahlagren E, Johansson S, Lindsted G, et al; (1992): Women with poly cystic ovary syndrome wedge resected in 1956 to 1965: a long-term follow- up focusing on natural history and circulating hormones. Fertile. Steril. 57; 505- 513.

8. Dunaif A (1995): Hyperandrogenemic anovulation (PCOS): a unique disorder of insulin action associated with an increased risk of non- insulin- dependent diabetes mellitus. Am. J. Med; (1A): 339- 398.

9. Dunaif A, Segal KR, Futterweit W, etal(1989): Profound peripheral insulin resistance, independent of obesity, in poly cystic ovary syndrome. Diabetes; 38: 11651174.

10. Ehrmann DA, Barnes RB, Rosenfield et al (1999): prevalence of impaired glucose tolerance and diabetes in women with polycystic overy syndrome Diabetes Care.; 22: 144- 146.

11. Ehrmann DA, Sturis j, Byrne MM; (1995): Insulin secretory defect in polycystic ovary syndrome. Relation ship to insulin sensitivity and family history of noninsulin dependent diabetes mellitus. Journal of clinical. Investing. 96: 520- 527.

12. Ferryman D, Gallwey JD(1961): Clinical assessment of body hair Growth in women. J. Clinical Endocrino and Metab; 21: 1440- 1447.

13. Flier J and Foster D (1997): Eating disorders obesity, Anorexia Nervosa and Bulimia Nervosa in: Wilson J and Foster D. (eds) Williams text book of Endocrinology WB sounders company USA. P; $1335-$ 1365.

14. Garg A, (1998): Dyslipoproteinemia and diabetes (review). Endocrinol. Metab. Clin North Am; 27: 613-625.

15. Gold Zieher JW, Young RL, (1992): Selected aspects of polycystic ovarion disease. Endocrinol. Metab. Clin. North. Am; 21: 141- 171 .

16. Haseltine F, Redmond GP, Colston A, (1994): Androgens and women's health clinician (NICHD) August; 12(No. 3): 132.

17. Hatch R, Rosenfield RL, Kim MH, Tredway D (1981): Hirsutism implications, etiology, and management. Am J obst. Gynecol; 140: 815- 830.

18. Judd H, and Yen S (1973): Serum Androstendione and testosterone levels during the menstrual cycle. J. clin. Endocrine, Metab, 36; 475- 477.

19. Kieren J. Mather, M.D, F.R.C.P.C, Flora Kwan M.D, et al (2000): Hyperinsulinemia in polycystic ovary syndrome correlates with increased cardiovascular risk 


\section{Indices of Free Testosterone And Hyperandrogenemia}

independent of obesity. Fertility and sterility J; 73 (No 1); 150- 156.

20. Konchenhaver Es, Key TT, KahsarMiller et al; (1998): Prevalence of the polycystic ovary syndrome in unselected black and white women of the south eastern united state:- a prospective study. J. clin. Endocr. Metab; 83: 3078- 3082.

21. Legro RS, Kunselman AR, Dodson WC, Dunaif A, (1999): Prevalence and predictors of risk for type 2 diabetes mellitus and impaired glucose tolerance in polycystic ovary syndrome: a prospective, controlled study in 254 affected women. J. clin. Endocrine. Metab; 84: 165- 169.

22. Nike M.M.L. stikkel broeck, Wim J.G et al (2003): Normal Bone Mineral Density and lean Body Mass, But Increased Fat Mass, In young adult patients with congenital Adrenal Hyperplasia. J. of Clin. Endocr. Metabo. 88(3): 1036- 1042.

23. Penttila TL, Koskinen P, Penttila TA, et al (1999): Obesity regulates bioavailable testosterone level in women with or without polycystic ovary syndrome. Fertile. Steril; 71: 427- 461.

24. Smith KD, Rodriguez- Rigou LJ, Tehololakian et al (1979): The relation between plasma testosterone level and the lengths of phases of the menstrual cycle. Fertile. Steril; 32; 403- 407.

25. Wild RA. (1995): Obesity Lipids, cardiovascular risk, and androgen excess. Am. J. med; 98(1A): 275- 325. 


\title{
معاملات التستوستيرون الحر وارتفاع هرمونات الأكورة في الام وعلاقتيه

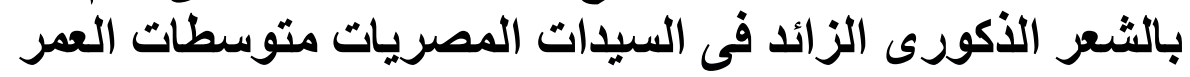

\author{
د. هناء طه قنديل* ـ د. زينب عبد الباسط حسن * د. دينا محمد اباظة* د. امل محمد

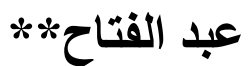

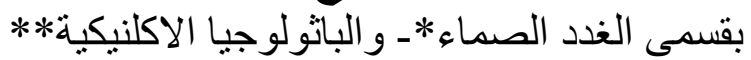 \\ بكلية طب بنات جامعة الاز هر
}

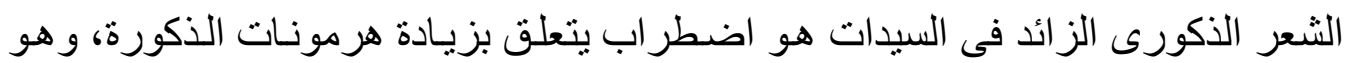

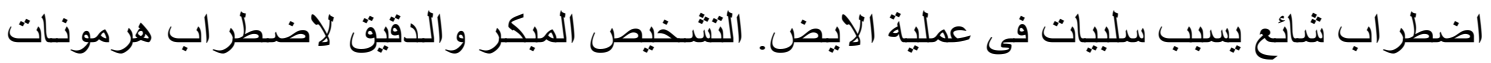

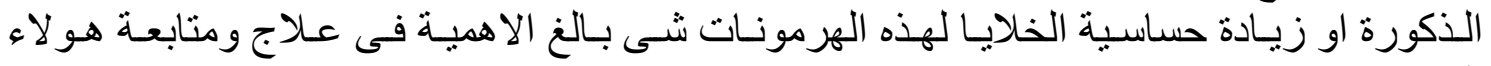

$$
\text { المرف من البحث: }
$$

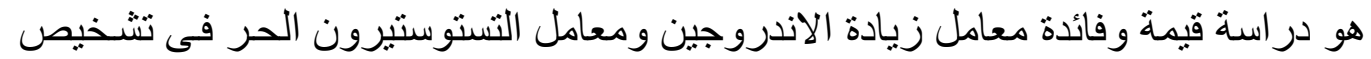

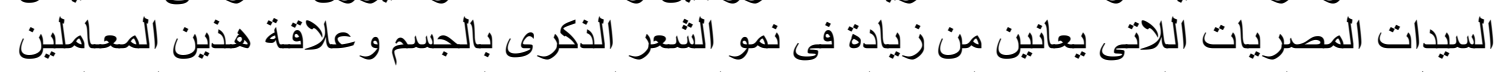

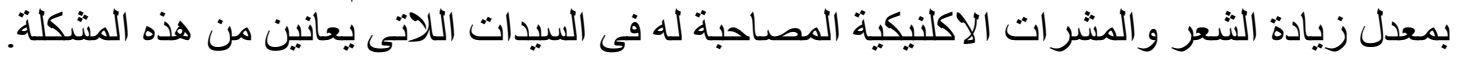

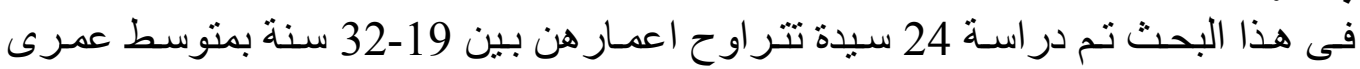

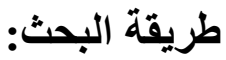

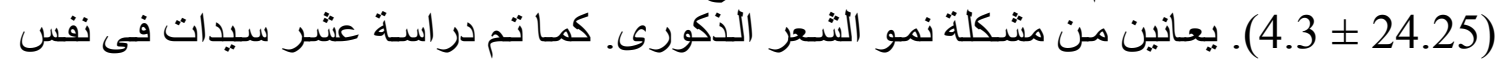

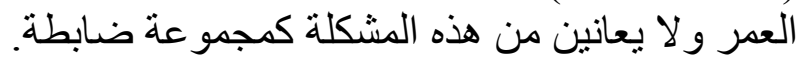

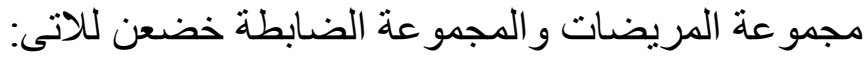
در اسـة تاريخ المرض وفحص اكلنيكى كامل، كمـات تم عمل التحاليل الكميائية و الهرمونيـة

O مكر صائم وبعد الاكل بساعتين.

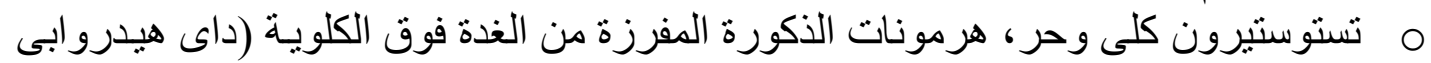

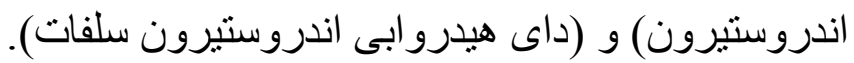

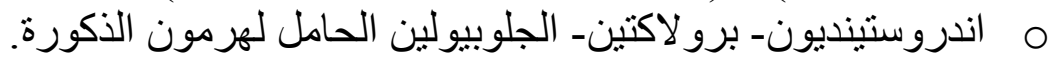
o O مانت النتائج كالاتى:

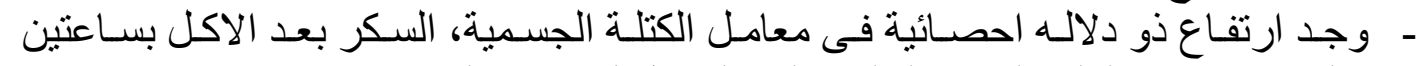

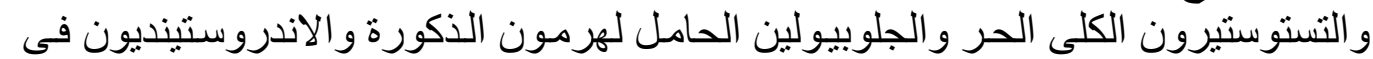
المجمو عة المريضة مقارنة بالمجمو عة الضابطة.

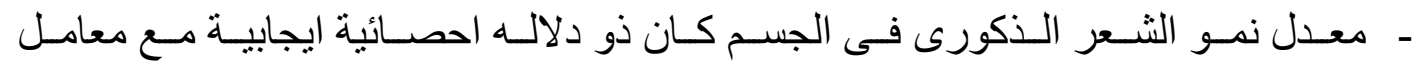
التستوستيرون الحر فقط وليس لـه علاقة بمعامل زيـادة الهرمونـات الذكريـة او الهرمونات التهات الاخرى كلا على حدة.

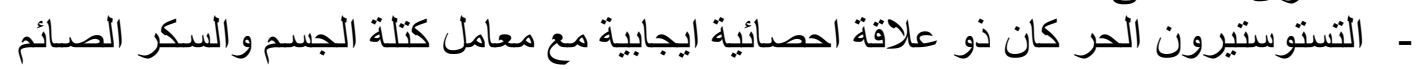

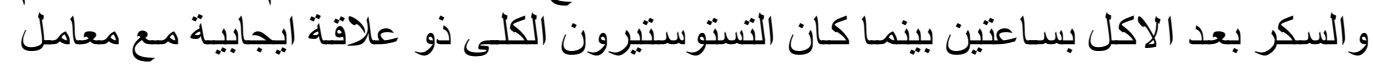
كتلة الجسم فقط.

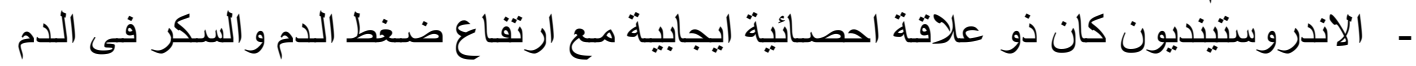
سو اء كان صائما او بعد الاكل بساعتين. 
- معامل زيادة التستوستيرون الحر كان ذو علاقة احصـائية ايجابية مع معدل نمو الثـعر

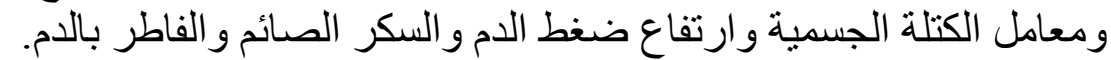

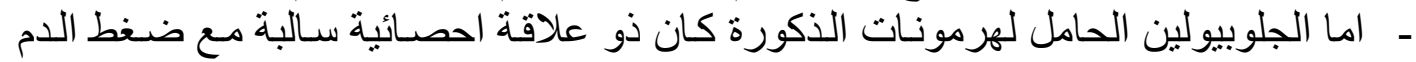
و السكر الصنائم وبعد الاكل بساعنين. ويستنتج من هذا البحث:

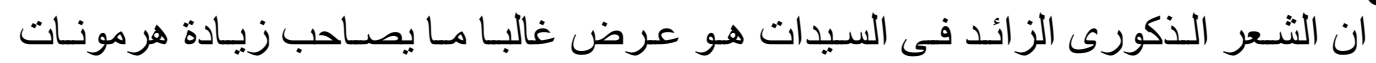
الذكورة وهذا لابد له من التشخيص المبكر النئ الدقيق كلما امكن.

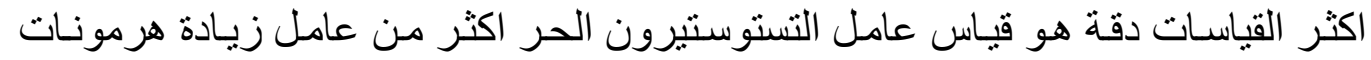

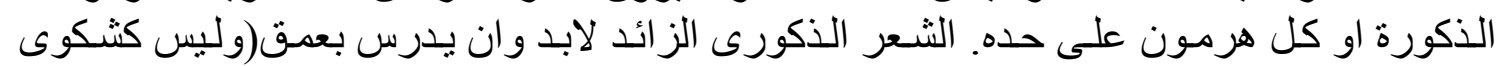
بسيطة) لانه ربما يكون مدخلا لمتلازمه ايضيه اكثر تعقيدا. 